ARTICLE

Check for updates

https://doi.org/10.1038/s43247-020-00067-6 OPEN

\title{
Higher than present global mean sea level recorded by an Early Pliocene intertidal unit in Patagonia (Argentina)
}

Alessio Rovere (1) ${ }^{1 凶}$, Marta Pappalardo (i) ${ }^{2}$, Sebastian Richiano ${ }^{3}$, Marina Aguirre ${ }^{4,5}$, Michael R. Sandstrom (1) ${ }^{6}$, Paul J. Hearty ${ }^{7}$, Jacqueline Austermann ${ }^{6}$, Ignacio Castellanos ${ }^{5} \&$ Maureen E. Raymo $^{6}$

Reconstructions of global mean sea level from earlier warm periods in Earth's history can help constrain future projections of sea level rise. Here we report on the sedimentology and age of a geological unit in central Patagonia, Argentina, that we dated to the Early Pliocene (4.69-5.23 Ma, 2 $\sigma$ ) with strontium isotope stratigraphy. The unit was interpreted as representative of an intertidal environment, and its elevation was measured with differential GPS at ca. $36 \mathrm{~m}$ above present-day sea level. Considering modern tidal ranges, it was possible to constrain paleo relative sea level within $\pm 2.7 \mathrm{~m}(1 \sigma)$. We use glacial isostatic adjustment models and estimates of vertical land movement to calculate that, when the Camarones intertidal sequence was deposited, global mean sea level was $28.4 \pm 11.7 \mathrm{~m}(1 \sigma)$ above present. This estimate matches those derived from analogous Early Pliocene sea level proxies in the Mediterranean Sea and South Africa. Evidence from these three locations indicates that Early Pliocene sea level may have exceeded $20 \mathrm{~m}$ above its present level. Such high global mean sea level values imply an ice-free Greenland, a significant melting of West Antarctica, and a contribution of marine-based sectors of East Antarctica to global mean sea level.

\footnotetext{
${ }^{1}$ MARUM-Center for Marine Environmental Sciences, University of Bremen, Leobener Str. 8., D-28359 Bremen, Germany. ${ }^{2}$ Department of Earth Sciences, Universitá degli studi di Pisa, Via S. Maria 53, 56126 Pisa, Italy. ${ }^{3}$ Instituto Patagónico de Geología y Paleontología, CONICET, Bv. Almirante Brown 2915 , Puerto Madryn (9120), Chubut, Argentina. ${ }^{4}$ CONICET, CCT-La Plata and Universidad Nacional de La Plata, Calle 8 n.1467, B1904CMC La Plata Buenos Aires, Argentina. ${ }^{5}$ Facultad de Ciencias Naturales y Museo, Universidad Nacional de La Plata, Calle 64 n.3, 1900 La Plata Buenos Aires, Argentina. ${ }^{6}$ Lamont Doherty Earth Observatory, Columbia University, 61 Rte 9W, Palisades, NY 10964, United States. ${ }^{7}$ Department of Geological Sciences, Jackson School of

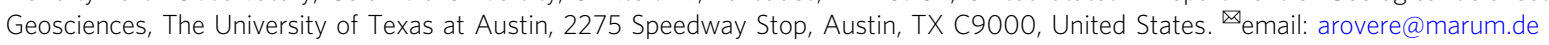


T he survey, interpretation and dating of paleo relative sea sevel (RSL) indicators (such as fossil coral reefs or relic beach deposits ${ }^{1}$ ) is paramount to constraining the maximum elevation reached by global mean sea level during periods of the Earth's history warmer than the pre-industrial. The elevation of paleo RSL indicators is the only direct proxy available to estimate global mean sea level in Earth's past. Once measured, observed paleo RSL indicators must be corrected for processes causing "Departures from Eustasy"2 (such as tectonics, mantle dynamic topography, DT, and glacial isostatic adjustment, $\mathrm{GIA}^{3,4}$ ) to obtain paleo global mean sea level (GMSL) estimates. These are in turn important to informing models of ice sheet melting under future warmer climates 5 .

A recent global database ${ }^{6}$ shows that about 5000 RSL indicators were preserved since the Last Glacial Maximum (30 ka). Wellpreserved and dated RSL indicators are relatively rare for older time periods: another compilation of Pleistocene RSL indicators ${ }^{7}$ reports more than 1000 Last Interglacial (MIS 5e, $125 \mathrm{ka}$ ) and only around 20 MIS 11 (400 ka) RSL indicators. Only a handful of sites exist that document sea level highstands beyond one million years ago ${ }^{2,8-11}$. In general, robust RSL indicators predating $400 \mathrm{ka}$ are rare to find because they are poorly preserved and are most often difficult to date with precision. In addition, relating them to GMSL is difficult since they are likely affected by significant postdepositional movements. This limits our ability to gauge the sensitivity of ice caps to warmer climate conditions, such as those that characterized Earth in the Pliocene.

Some of the oldest, precisely dated and measured RSL indicators were recently reported on the island of Mallorca (Balearic Islands, Spain), in a coastal cave called "Coves d'Artá". Here, six phreatic overgrowths on speleothems mark the paleo water/air interface within the cave ${ }^{9}$, and are therefore closely related to paleo RSL. The highest and oldest of these formations was measured at $31.8 \pm 0.25$ $\mathrm{m}$ above mean sea level, and yielded a U-Pb age of $4.29 \pm 0.39 \mathrm{Ma}$ $(2 \sigma)^{9}$. Taking into account GIA and possible long-term deformation due to tectonics or dynamic topography, it was estimated that global mean sea level at the time of deposition of this RSL indicator was $25.1 \mathrm{~m}$ above present, bounded by uncertainties represented by 16th-84th percentiles of $10.6-28.3 \mathrm{~m}^{9}$. For the same time period, a second study ${ }^{10}$ reported a site in the Republic of South Africa (Northern Cape Province, site Cliff Point-ZCP Section2). Here, oyster shells living in a paleo subtidal to intertidal environment constrain paleo RSL at $35.1 \pm 2.2 \mathrm{~m}(1 \sigma)$. The oysters were dated to $4.28-4.87 \mathrm{Ma}$ ( $2 \sigma$ range) with strontium isotope stratigraphy (SIS). While paleo global mean sea level estimates were not calculated at this site, based on the Mallorca benchmark the authors argue that this location was affected by relatively minor vertical land movements (possibly uplift) since $5 \mathrm{Ma}$.

While indirect paleo sea level estimates spanning the last $5.3 \mathrm{Ma}$ are available from oxygen isotopes ${ }^{12-14}$, the two studies cited above are arguably the only ones reporting relatively precise and well-dated direct sea-level observations for the Early Pliocene, that is regarded as a past analog for future warmer climate ${ }^{15}$. At this time, $\mathrm{CO}_{2}$ was between pre-industrial and modern levels, with possibly higher peaks to $450 \mathrm{ppm}^{15,16}$. During Early Pliocene interglacials, average global temperatures were $2-3^{\circ} \mathrm{C}$ higher than pre-industrial values ${ }^{15,17}$. Pliocene climate was modulated by a ca. $40 \mathrm{kyr}$ periodicity in glacial/interglacial cycles with highstands and lowstands that were characterized by sea-level oscillations as high as $13 \pm 5 \mathrm{~m}^{18}$. Ice models suggest that, during the warmest Pliocene interglacials, Greenland was ice-free ${ }^{19}$. Similarly, they suggest that the West Antarctic Ice sheet was likely subject to periodic collapses ${ }^{20}$, and might have contributed as much as $7 \mathrm{~m}^{21}$ to GMSL. Ice models and field-based evidence ${ }^{22}$ suggest that also the East Antarctic Ice Sheet might have been smaller than today, contributing another $3 \mathrm{~m}^{21}$ to $13-16 \mathrm{~m}^{23}$ to GMSL.
In this study, we report a foreshore (intertidal) sequence located in the town of Camarones, along the coast of central Patagonia, Argentina (Fig. 1). Combining field data, SIS ages, GIA and DT models we conclude that this deposit formed 4.69-5.23 Ma ago ( $2 \sigma$ range) when sea level was $28.4 \pm 11.7(1 \sigma)$ higher than today. This estimate is broadly consistent with those derived from the Republic of South Africa and Spain. Together, these three studies present a coherent picture of global mean sea level during the Early Pliocene, that likely exceeded $20 \mathrm{~m}$ above modern sea level.

The Patagonia geographic region includes territories belonging to the states of Argentina and Chile. Geologically, Patagonia represents the southernmost tip of the South American plate (Fig. 1a). Along the Pacific coasts of Patagonia, the Nazca and the Antarctic plates are subducting below the Andes. Towards the south, the Scotia plate moves eastward and outlines Tierra del Fuego, at South America's southern tip ${ }^{24}$. To the East, the Patagonian Atlantic coast is a passive margin, tectonically characterized as an extensional stress field and bordered by a wide continental shelf. The central and eastern parts of this landmass are represented by the Andean foreland, formed by a Paleozoic-Mesozoic metamorphic basement overlapped by Tertiary continental and marine sedimentary rocks, dating back to the Paleocene. These are covered by Eocene-Oligocene pyroclastic rocks and Middle Miocene fluvial sediments. Marine sedimentary rocks corresponding to Tertiary transgressions are located east of the Andean foreland ${ }^{25}$. In the Middle Miocene, the Chile Triple Junction migrated northward, leading to the opening of an asthenospheric window below southern Patagonia ${ }^{26}$. This caused a switch from subsidence to uplift, and the Patagonia region underwent a moderate but continuous uplift ${ }^{27}$.

Along the coastlines of Central Patagonia, several levels of paleo shorelines above modern sea level were noted by Charles Darwin in his Beagle voyage ${ }^{28}$, and were the subject of more than 150 years of research (See Supplementary Note 1 and Supplementary Table 1). Studies of Pleistocene coastal sequences in Central Patagonia include outcrops of Holocene ${ }^{29,30}$, Pleistocene $e^{31-33}$, and Pliocene-to-Miocen $e^{34,35}$ age. Among the latter, Del Río et al..$^{35}$ dated Early Pliocene mollusks from marine deposits few hundreds of kilometers south of the study area described in this study.

The town of Camarones lies at the northern tip of the San Jorge Gulf, $\sim 1300 \mathrm{~km}$ south of Buenos Aires. Within a few kilometers of Camarones, several paleo-sea level indicators have been preserved, from the Holocene ${ }^{36}$ to the Pleistocene ${ }^{31}$. Already in the late 1940s, the Italian geologist Feruglio ${ }^{37}$ identified an elevated marine terrace along a roadcut carved on the main road leading into the town of Camarones that he tentatively attributed to the Pliocene. He called this terrace, the Camarones High Terrace (originally, in Spanish, Teraza Alta de Camarones ${ }^{37}$ ). A recent study ${ }^{31}$ confirmed the elevation of the Camarones High Terrace at ca. $40 \mathrm{~m}$ above sea level, at the lower bound of the "beach barries and terrace deposits between 40 and $110 \mathrm{~m}$ elevation" reported by the 1:250.000 geological chart of Camarones ${ }^{38}$.

\section{Results}

Pliocene sea level record at Camarones and GMSL estimates. Radiometric ages, precise GPS elevations and stratigraphic descriptions of cross-sections surveyed along the Camarones High Terrace are the subject of this paper. Along this terrace, we surveyed and dated samples from two sites, separated by less than one kilometer. One is the Roadcut, already recognized and described by Feruglio ${ }^{37}$. We did not find reports of the second site (that we here call Caprock, Fig. 1b) in the existing literature, although it is possible that it was included in the geological description of the High Terrace by previous authors. At both sites, we recognized a geological facies representative of sedimentation in a foreshore environment 


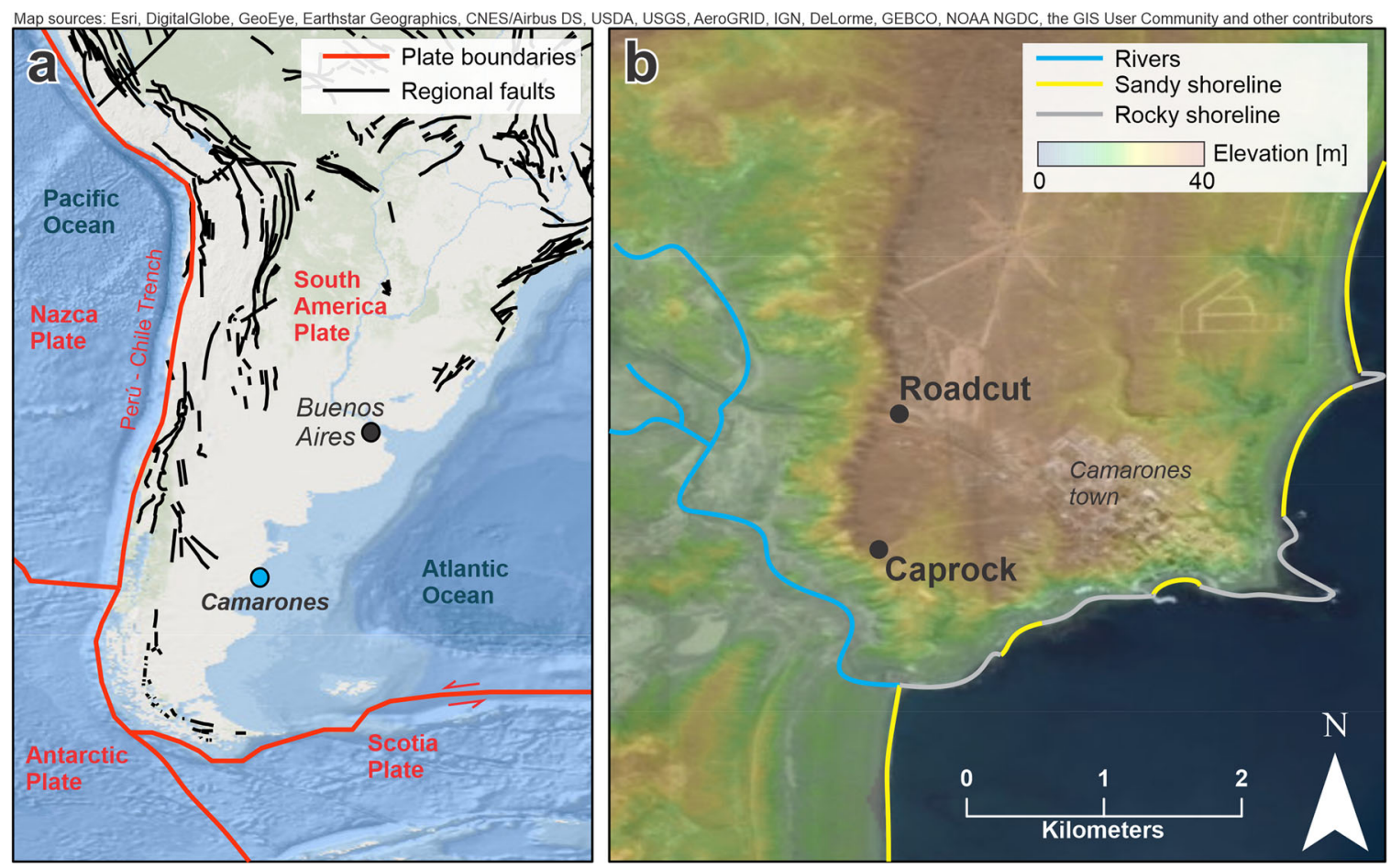

Fig. 1 General and specific location of the study area. a Location of the study area and main geological structures in the Southern part of South America. b Topography of the Camarones town area, with location of the two outcrops (Roadcut and Caprock) presented in this study. Map sources: Esri, DigitalGlobe, GeoEye, Earthstar Geographics, CNES/Airbus DS, USDA, USGS, AeroGRID, IGN, DeLorme, GEBCO, NOAA NGDC, SRTM, the GIS User Community and other contributors. Elevation data in $\mathbf{b}$ are from the Shuttle Radar Topography Mission ${ }^{79}$.

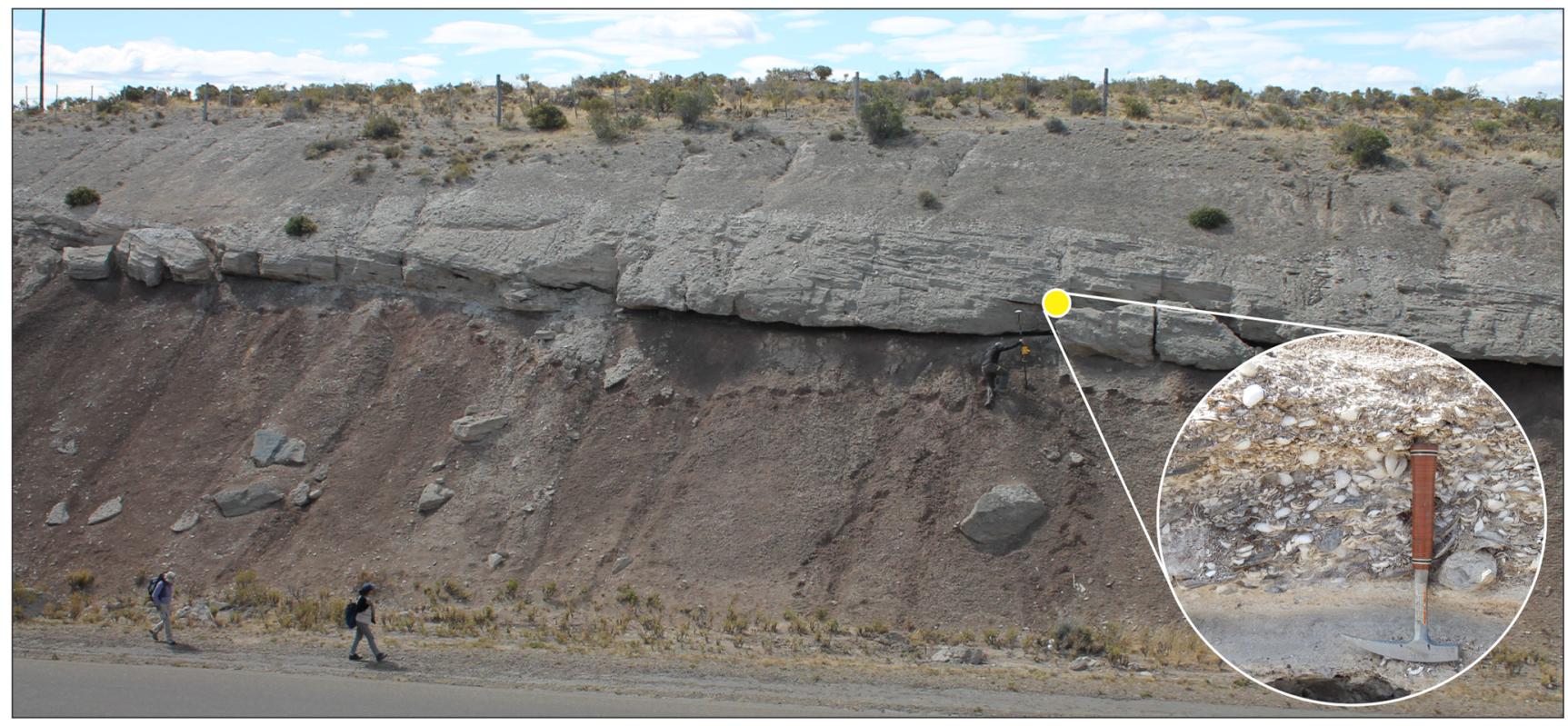

Fig. 2 The Roadcut outcrop at Camarones. The inset shows a detail of Unit $\mathbf{C p}$, a shelly-rich layer interpreted as representative of a foreshore (intertidal) environment dating to the Early Pliocene. Each unit is described in details in the Supplementary Note 2, including descriptions of the Caprock outcrop.

(i.e., in the intertidal zone) that marks paleo RSL with high accuracy. All data described hereafter and in Supplementary Note 2 is available in spreadsheet form from Rovere et al. ${ }^{39}$.

Paleo RSL. In general, Roadcut and Caprock represent sedimentation during a transgressive event on top of a raised shore platform (Supplementary Figs. 1-2). Among the units identified within the Roadcut (Fig. 2), one (Unit Cp, see inset in Fig. 2) is composed of well-cemented fine conglomerates with rounded pebbles and shells. In particular, the uppermost part of this unit contains a dense faunal assemblage in the form of a shellbed, where we recognized 15 different species of bivalves and 11 species of gastropods (Supplementary Table 2). The bivalve shells are mostly intact and sometimes with paired valves (articulated), but not in living position. This unit was interpreted as representative of a foreshore environment, i.e., the intertidal zone. The same unit has been identified at the Caprock section, at roughly the 
Table 1 GPS position and elevation of Unit Cp measured at the Roadcut and Caprock sites. Lat/Lon are in WGS84 coordinates, Ellipsoid heights are referred to the ITRF08 ellipsoid, geoid heights to the GEOIDEAR16 geoid model.

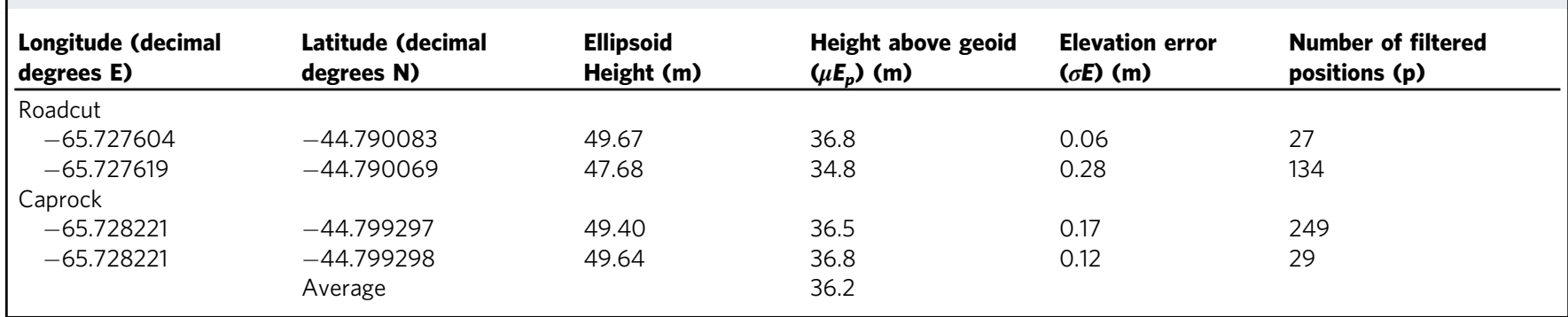

same elevation. The elevation of Unit $\mathrm{Cp}$ was measured at two points at both Roadcut and Caprock (Table 1). From these measurements, we calculate that Unit $C p$ has an average elevation of $36.2 \pm \mathbf{0 . 9} \mathbf{~} \mathbf{( 1 \sigma})$ above the GEOIDEAR16 geoid $^{40}$, which is the best approximation for present sea level in Argentina. Using modern tidal values ${ }^{36}$, and assuming no post-depositional movement, we calculate that the two outcrops in the area of Camarones are indicative of a paleo RSL at $36.2 \pm 2.7 \mathrm{~m} \mathrm{(1 \sigma )}$ above present (see "Methods" section for details).

Age. Three oyster shells from Roadcut and Caprock were analyzed by strontium isotope stratigraphy (SIS) relative dating techniques. Using sequential leaching to target the least altered inner carbonate of each shell, we obtained multiple SIS ages on three different shells (one from Caprock and two from Roadcut; see Sandstrom et al. ${ }^{11}$ for a detailed description of the adopted methodology). The shells yielded an age range of 4.69-5.23 Ma $\left(n=6,2 \sigma \mathrm{S}_{\mathrm{EM}}\right)$.

Glacial isostatic adjustment. The Early Pliocene intertidal units surveyed at Camarones were subject to processes that caused their past and current elevation to depart from GMSL. These include glacial isostatic adjustment (GIA) and other vertical land motions (VLMs). We calculate GIA using 36 different Earth models. For this site, we calculate a GIA correction of $-14.6 \pm 3.2 \mathrm{~m}(1 \sigma)$ (see "Methods" section for details). This value is subtracted from the observed paleo RSL and the uncertainty propagated. This correction is a combination of effects associated with (i) the ongoing response to the last deglaciation, and (ii) Antarctic ice sheet oscillations during the early Pliocene ${ }^{2}$. The former contribution is $-9.5 \pm 3 \mathrm{~m}(1 \sigma)$, which means that the Argentinian coast today experiences sea level fall due to a combination of effects associated with postglacial rebound due to the melting of the glacial Patagonian ice sheet, as well as continental levering, ocean syphoning, and rotational effects. Once fully relaxed, sea level at Camarones will therefore be lower (and a paleo sea level indicator higher) by $\sim 9.5 \mathrm{~m}$ than it is today. The additional contribution of $\sim-5 \mathrm{~m}$ is associated with the adjustment to $40 \mathrm{kyr}$ oscillations in the Antarctic ice sheet. The result is that, at Camarones, GIAcorrected paleo RSL is $50.8 \pm 4.2 \mathrm{~m}(1 \sigma)$.

Vertical land motions. The GIA-corrected RSL elevation reported above needs to be further corrected for VLMs, that can be either due to crustal tectonics, mantle dynamic topography 41,42 or deformation associated with sediment loading/unloading ${ }^{43,44}$. As briefly outlined in the previous sections, Camarones is located on a passive margin, likely subject to limited tectonic influence. Dynamic topography models suggest that, since MIS 5e (125 ka), the area of Camarones was subject to uplift, with rates increasing towards the South ${ }^{3}$. This is in line with observations of much higher Pliocene shorelines (70-170 $\mathrm{m}$ above sea level ${ }^{35}$ ) at locations 300-500 km south of Camarones (Supplementary Note 1).

\begin{tabular}{|c|c|c|c|c|}
\hline Reference & Model & VLM (m) & Timing (Ma) & Rate (m/Ma) \\
\hline \multirow[t]{7}{*}{ Müller et al. ${ }^{46}$} & M1 & 4.6 & 10 & 0.46 \\
\hline & M2 & 66.2 & 10 & 6.62 \\
\hline & M3 & 45.0 & 10 & 4.50 \\
\hline & M4 & 58.0 & 10 & 5.80 \\
\hline & M5 & 45.4 & 10 & 4.54 \\
\hline & M6 & 21.8 & 10 & 2.18 \\
\hline & M7 & 25.5 & 10 & 2.55 \\
\hline \multirow[t]{4}{*}{ Flament et al. 45} & Case 1 & 35.7 & 5 & 7.14 \\
\hline & Case 2 & 37.6 & 5 & 7.52 \\
\hline & Case 3 & 22.9 & 5 & 4.58 \\
\hline & Case 4 & 18.6 & 5 & 3.73 \\
\hline
\end{tabular}

Predictions are given at the time step closest to the sea level indicator age, which is denoted as 'Timing'. Rates are calculated based on this age and the predicted VLM and linearly interpolated to the age of the indicator.

A long-term slight uplift trend is also predicted by the models of Flament et al. ${ }^{45}$ and Müller et al. ${ }^{46}$. Predictions in these DT models average to $4.5 \pm 2.2 \mathrm{~m} / \mathrm{Ma}$ (Table 2). Accounting for the age of the deposit (including $1 \sigma$ uncertainties), this leads to a downward correction of our global mean sea level inference by $22.4 \pm 11.0 \mathrm{~m}(1 \sigma)$. As is apparent from the variation of estimates for the dynamic topography rate, this correction remains quite uncertain and the true value can possibly be even outside of this range given that it is difficult to fully explore model uncertainties (see "Discussion" section).

Global mean sea level. Using the value of VLM reported above and propagating the uncertainties related to RSL, GIA, and VLM, we calculate that, at the time of deposition of the Caprock and Roadcut outcrops, GMSL was $28.4 \pm \mathbf{1 1 . 7} \mathbf{m}(\mathbf{1} \sigma)$. We remark that there are large unknowns associated with this value. First, as described above, dynamic topography remains a process that has high uncertainties that are generally not fully quantified. Second, it is possible that, as it is the case for the US Atlantic Coastal Plain $^{43}$, flexural response to sediment loading or tectonic deformation (that are not considered here) could also contribute to further vertical land motions in this area.

\section{Discussion}

Our results show that the intertidal units at Camarones are of Early Pliocene age (4.69-5.23 Ma, $\left.2 \sigma \mathrm{S}_{\mathrm{EM}}\right)$. The sedimentological and stratigraphic characteristics of the deposits analyzed in this study lead to the conclusion that they formed during a sea level highstand, when GMSL was $28.4 \pm 11.7 \mathrm{~m}(1 \sigma)$ higher than present. We note that there are still large uncertainties on this GMSL 


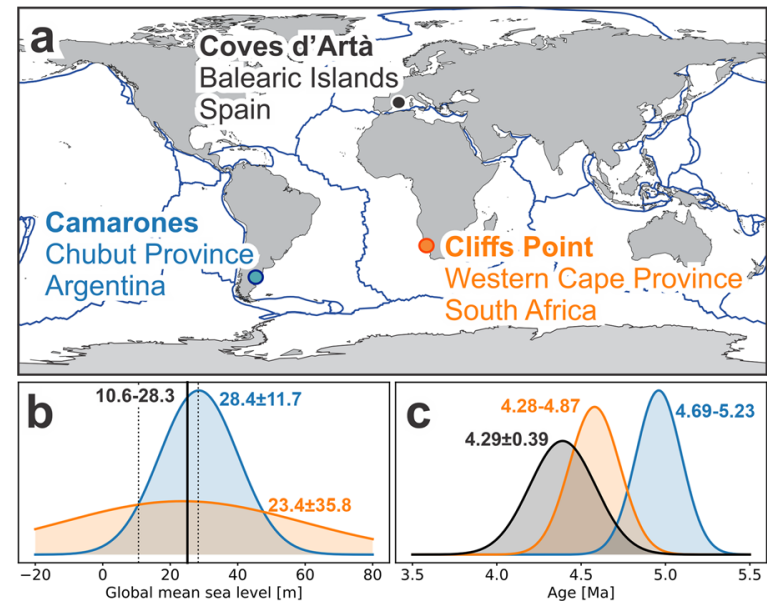

Fig. 3 Comparison among early Pliocene sea level stratigraphic

reconstructions. a Location of Early Pliocene RSL indicators discussed in the text. Plate boundaries are shown in dark blue for reference ${ }^{76}$. b Global Mean Sea Level (GMSL) estimates for: (i) Coves d'Arta (Balearic Islands, Spain), solid black line represents the most likely value $(25.1 \mathrm{~m})$, dotted black lines the 16th and 84th percentiles9; (ii) Camarones, Argentina (blue gaussian); (iii) Cliffs Point, South Africa (orange gaussian, calculated from data in Hearty et al. ${ }^{10}$, corrected with the same GIA and subset of applicable DT models used for Camarones. c Age estimates for Coves d'Arta (black), Camarones (blue) and Cliffs Point (orange).

estimate, which derive mostly from vertical land motion corrections, stemming from the variability of published dynamic topography predictions $\mathrm{s}^{45,46}$. Exploring and reducing these uncertainties requires improved mapping of the mantle structure beneath Patagonia from seismic tomography, a better understanding of how wave speeds map into density variations, and improved constraints on the rheology of the subsurface. Recent advances tackle these shortcomings and promise to reduce uncertainties in the estimate of vertical land motion ${ }^{47,48}$. Another strategy to investigate vertical land motions at Camarones would be to use the Pleistocene shorelines at the same site to extract a long-term uplift rate for the area. We argue that such approach would lead to similarly large error bars due to uncertainties related to GIA, Pleistocene global mean sea level and the implicit assumption that uplift rates can be linearly extrapolated over these time scales ${ }^{49}$.

Despite the uncertainties related to VLMs, there is overlap between the calculated global mean sea levels for Camarones $(28.4 \pm 11.7 \mathrm{~m}, 1 \sigma)$ and Coves d'Artá (Spain ${ }^{9}, 25.1 \mathrm{~m}$, with 16th-84th percentiles of 10.6-28.3 m, Fig. 3a,b). Correcting the proxy record at Cliffs Point (South Africa ${ }^{10}$ ) with the same GIA models used for Camarones (Table 3), results in a paleo RSL of $44.7 \pm 2.7 \mathrm{~m}(1 \sigma)$ above present. The DT model predictions by Müller et $\mathrm{al.}^{46}$, which were also used for Camarones, indicate VLMs in the range of $4.6 \pm 7.8 \mathrm{~m} / \mathrm{Ma}(1 \sigma)$. This results in an average global mean sea level estimate that aligns with those obtained from the other two sites, but bounded by very large uncertainties $(23.4 \pm 35.8 \mathrm{~m}, 1 \sigma)$, (Fig. $3 \mathrm{~b})$. As already underlined by Hearty et al. ${ }^{10}$, improving uplift estimates for this region is paramount to enable the use of RSL data in GMSL calculations.

The average global mean sea level calculated from the geological facies reported in Argentina (this study), South Africa ${ }^{10}$ and Spain ${ }^{9}$ is well above modern sea level. Compared to published global mean sea level estimates that are based on ice sheet models and indirect sealevel proxies (Fig. 4), it is evident that field evidence is most consistent with the highstands obtained by scaling the Lisiecki and Raymo (2004) ${ }^{50}$ benthic oxygen isotope stack (see "Methods" section

\begin{tabular}{|c|c|c|c|c|}
\hline Location & Longitude & Latitude & $\mu G I A(\mathrm{~m})$ & $\sigma G I A(\mathrm{~m})$ \\
\hline Argentina & $65.73^{\circ} \mathrm{E}$ & $44.79^{\circ} \mathrm{S}$ & -14.6 & 3.2 \\
\hline South Africa & $18.12^{\circ} \mathrm{W}$ & $31.59^{\circ} \mathrm{S}$ & -9.6 & 1.6 \\
\hline Mallorca & $3.45^{\circ} \mathrm{W}$ & $39.66^{\circ} \mathrm{N}$ & 2.9 & 2.2 \\
\hline Mallorca99 & $3.45^{\circ} \mathrm{W}$ & $39.66^{\circ} \mathrm{N}$ & 1.3 & 3.1 \\
\hline
\end{tabular}

For comparison, we also report the results for Mallorca used in Dumitru et al. ${ }^{9}$

for details). Our data is also consistent with some peaks predicted by the one-dimensional ice sheet model of Stap et al..$^{51}$. Other ice sheet model based estimates ${ }^{52-54}$ significantly under predict the observed Early Pliocene sea level records presented here. The almostcontinuous Gibraltar record ${ }^{12}$, derived from planktic $\delta^{18} \mathrm{O}$ coupled with a hydraulic model, largely over predicts sea level observed at both Argentina and Spain suggesting that, when the Camarones outcrop was deposited, the Earth was substantially ice-free. To align with this record, the three sites in this study would have to be characterized by marked subsidence, instead of uplift as indicated by almost all dynamic topography models we considered. Early Pliocene observations from Argentina only overlap with lowstands of the Gibraltar record, which would have left regressive imprints. This is at odds with the sedimentological characteristics of the Roacut, which represents a transgressive system rather than a regressive one.

While GMSL estimates from South Africa ${ }^{10}$ are affected by large uncertainties, their average value together with the Argentinian sealevel proxies presented in this study and those obtained from Spain ${ }^{9}$, suggest that Early Pliocene GMSL might have exceeded 20 $\mathrm{m}$ above present-day levels. Reaching the average GMSL calculated for Camarones $(28.4 \mathrm{~m}$ ) would require an ice-free Greenland (GrIS, $7.4 \mathrm{~m}$ sea-level equivalent ${ }^{55}$ ), significant melting of the West Antarctic Ice Sheet (WAIS, $3.3 \mathrm{~m}$ sea-level equivalent ${ }^{56}$ ) and the almost complete melting of marine sectors of the East Antarctic Ice Sheet (EAIS, $19 \mathrm{~m}$ sea-level equivalent ${ }^{57}$ ). Reaching the lower end calculated for Camarones $(16.7 \mathrm{~m}, 1 \sigma$ below the mean) would require complete melting of the GrIS and WAIS, and melting of about $1 / 3$ of the marine-based sectors of the EAIS. This scenario would match almost exactly a complete GrIS melting, and a contribution from Antarctica in line with the one modeled by Golledge et al. ${ }^{58}$. These authors calculated that the contribution of Antarctica to GMSL during an Early Pliocene (4.23 Ma) interglacial was $8.5 \mathrm{~m}$, sourced primarly from WAIS and the Wilkes subglacial basin of EAIS. Reaching the upper end calculated for Camarones $(40.1 \mathrm{~m}, 1 \sigma$ above the mean) would require significant contributions of not only marine-based but also land-based sectors of the EAIS in addition to melting of the GrIS and WAIS. We note that geological proxies suggest that a significant melting of land-based portions of EAIS was unlikely over the past 8 million year ${ }^{59}$, which makes this last scenario less likely.

\section{Conclusion}

The Early Pliocene world was characterized by global annual mean temperatures of $2-3^{\circ} \mathrm{C}$ higher than pre-industrial, and $\mathrm{CO}_{2}$ levels between 280 and $450 \mathrm{ppm}^{15}$. In face of these relatively small differences in temperature and $\mathrm{CO}_{2}$, the Earth's climate was substantially different than today ${ }^{16}$, and ice sheets were significantly smaller. Until recently, field evidence to support the answer to the question "How high was global mean sea level in the Early Pliocene?" was elusive. In this study, we show that independent paleo sea-level indicators of similar age on three continents result in broadly similar GMSL estimates. While affected by large uncertainties, stemming mostly from vertical 


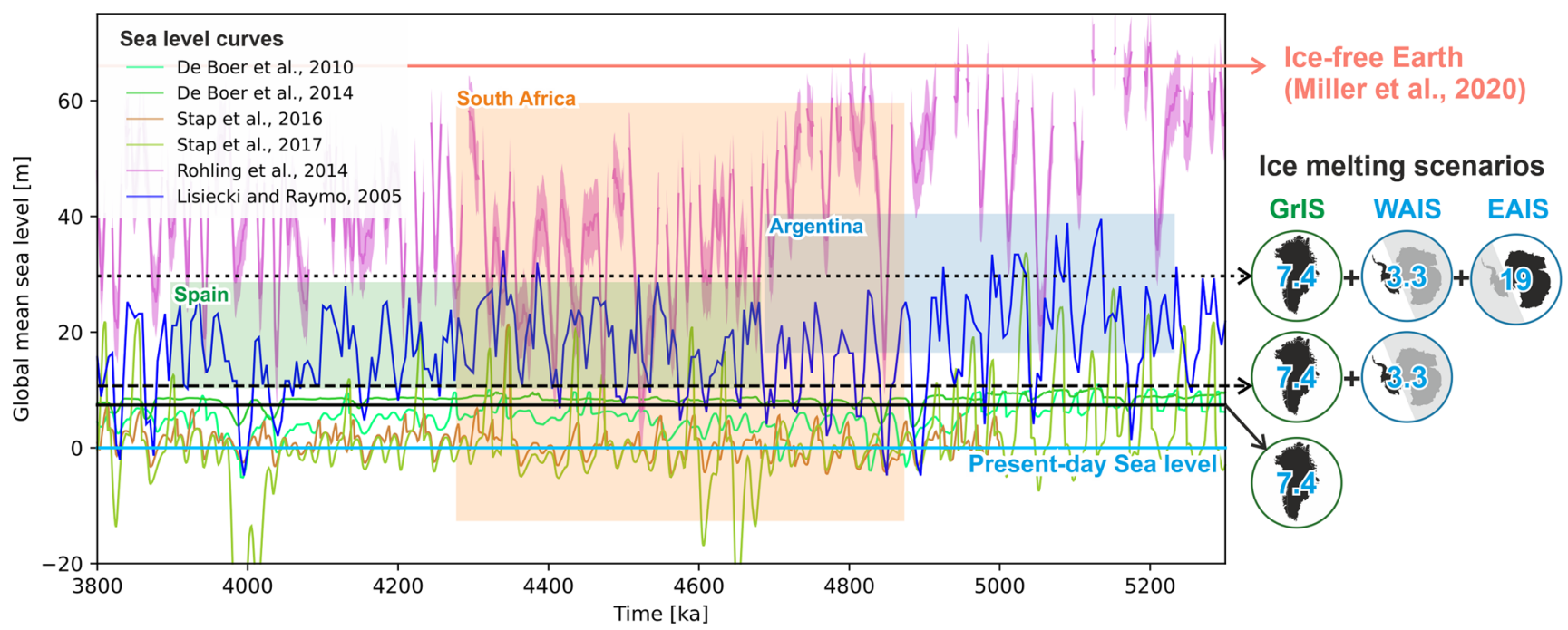

Fig. 4 Comparison between sea-level data discussed in this study and global mean sea level derived from ice models ${ }^{51-54}$ and indirect sea level proxies ${ }^{12,50}$. The blue curve shows the GMSL prediction that is used in the GIA model and based on scaling the benthic oxygen isotope record by Lisiecki and Raymo (2005) 50 following the steps described in the methods. Age ranges for observations are $2 \sigma$, while elevation ranges are $1 \sigma$ for Argentina and South Africa, and 16th-84th percentiles for Spain. Horizontal black lines and graphics on the right side of the graph show total sea level equivalent for icefree Greenland (GrIS, solid line ${ }^{55}$ ), melting of West Antarctic Ice Sheet (WAIS, dashed line ${ }^{56}$ ) and marine sectors of the East Antarctic Ice Sheet (EAIS, dotted line ${ }^{57}$ ). The upper red line shows GMSL in an ice-free Earth, estimated to $66 \mathrm{~m}$ by Miller et al. ${ }^{14}$.

land motion estimates, they indicate that Early Pliocene sea level may have exceeded $20 \mathrm{~m}$ above present-day. This value can be attained only with a complete melting of the Greenland ice sheet and significant contributions of Antarctica (also including marine-based sectors of East Antarctica).

The significance of the Early Pliocene and its potential role as analog for present-day and near-future warming must be taken into account as the world prepares to meet the "Paris Agreement"60 goals and limit global warming below the $1.5^{\circ} \mathrm{C}$ threshold ${ }^{61}$.

\section{Methods}

Elevation measurements and paleo RSL estimates. We measured elevations with a differential GPS system (Trimble ProXRT receiver and Trimble Tornado antenna) equipped to receive OmniSTAR HP real-time corrections. As per technical specifications by the service provider, these corrections allow to measure, in

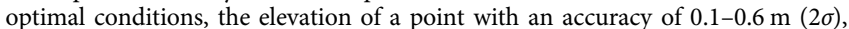
depending on the survey conditions. We remark that, while at the Caprock outcrop there is a free view of the sky, at the Roadcut satellite reception is hindered by the vertical cliff face. This could explain, in part, the discrepancy in the two points collected at this outcrop at relatively short distance from each other. Data were originally recorded in geographic WGS84 coordinates and in height above the ITRF2008 ellipsoid. For each GPS point, we calculated heights above Mean Sea Level (orthometric height) subtracting from the measured ITRF2008 ellipsoid height the GEOIDEAR16 geoid height ${ }^{40}$. These geoidal elevations are the best available approximation of mean sea level in this area. GEOIDEAR16 was estimated to have an overall accuracy of $10 \mathrm{~cm}$ (https://www.ign.gob.ar/

NuestrasActividades/Geodesia/Geoide-Ar16). The location and elevations of Unit $\mathbf{C p}$ at Roadcut and Caprock are reported in Table 1.

From these elevations, we calculate that the average elevation $(\mu E)$ is $36.2 \mathrm{~m}$. To calculate the elevation error $(\sigma E)$, we use the following formula:

$$
\sigma E=\sqrt{\frac{\sum_{1}^{N}\left(\sigma E_{p}^{2} \cdot(p-1)\right)+p \cdot\left(\mu E-\mu E_{p}\right)}{N-1}}
$$

where $\mathrm{N}$ is the total number of filtered positions measured by the GPS during the survey (439, sum of "Number of filtered positions" in Table 1), $\sigma E_{p}$ is the elevation error for each single point, $\mu E_{p}$ is the Height above geoid of each single point and $\mu E$ is the average elevation (36.2 m) (Table 1). On average, we calculate that the elevation of Unit $\mathbf{C p}$ is $36.2 \pm 0.9 \mathrm{~m}(1 \sigma)$.

The Unit $\mathbf{C p}$ at the Roadcut and Caprock sites has been interpreted as forming in the foreshore zone, i.e., in the intertidal zone. This means that its indicative meaning $^{62}$ spans from Mean Lower Low Water (MLLW) to Mean Higher High Water (MHHW). Based on predicted tidal data for the harbor of Camarones, Bini et al. ${ }^{36}$ report that the maximum tidal range (MHHW to MLLW) in Camarones is $5 \mathrm{~m}$. We use this value $(5 \mathrm{~m})$ as the indicative range (IR) for a foreshore deposit in our area, and the midpoint between MHHW and MLLW $(0 \mathrm{~m})$ as reference water level (RWL). Then, using the formulas described in Rovere et al. ${ }^{1}$, we calculate paleo RSL and its associated uncertainty as follows:

$$
\begin{gathered}
\mathrm{RSL}=\mu E-\mathrm{RWL} \\
\sigma \mathrm{RSL}=\sqrt{\sigma E^{2}+\left(\frac{\mathrm{IR}}{2}\right)^{2}}
\end{gathered}
$$

Using the equations above, we calculate that paleo RSL associated with Unit $\mathbf{C p}$ is $36.2 \pm 2.7 \mathrm{~m}$. We highlight that this value does not take into account the possibility that, $5 \mathrm{Ma}$ ago, tidal ranges were different than present-day ones, due to different shelf bathymetry under higher sea levels ${ }^{63}$.

To calculate global mean sea level (GMSL) and associated uncertainties, we used the following formulas:

$$
\mathrm{GMSL}=\mathrm{RSL}-\mu \mathrm{GIA}-\mu \mathrm{VLM}
$$

where $\mu$ GIA is the average of the GIA models (Table 3) and $\mu$ VLM is calculated as the product of mean dynamic topography rate (Table 2) multiplied by the average age of the deposit.

$$
\sigma \mathrm{GMSL}=\sqrt{\sigma \mathrm{RSL}^{2}+\sigma \mathrm{GIA}^{2}+\sigma \mathrm{VLM}^{2}}
$$

where $\sigma G I A$ is the standard deviation of GIA models shown in Table 3 and $\sigma \mathrm{VLM}$ is calculated as follows:

$$
\sigma \mathrm{VLM}=|\mathrm{VLM}| \cdot \sqrt{\left(\frac{\sigma \text { Age }}{\mu \text { Age }}\right)^{2}+\left(\frac{\sigma \text { Rate }}{\mu \text { Rate }}\right)^{2}}
$$

where $\mu$ Age and $\sigma$ Age are the average and $1 \sigma$ age of the deposit, and $\mu$ Rate and $\sigma$ Rate are the average and $1 \sigma$ rates derived from published dynamic topography models (Table 2).

Strontium isotope stratigraphy ages. To attribute an age to Unit $\mathbf{C p}$, we used the Strontium Isotope Stratigraphy (SIS) curve published by McArthur et al. ${ }^{64}$ (LOWESS version 5). Sr isotope ratios from carbonates are susceptible to postdepositional alteration, therefore, any significant reworking of $\mathrm{Sr}$ isotopes needs to be detected and discarded. Information on shell preservation was determined using ${ }^{87} \mathrm{Sr} /{ }^{86} \mathrm{Sr}$ measurements on sequentially leached shell material (assuming smaller $\mathrm{Sr}$ isotope variations between leaches implies better preservation ${ }^{65,66}$ ) alongside standard screening techniques ${ }^{35,67}$ and elemental analysis $\left.{ }^{68,69}\right)$. A preservation index between " 1 " (unaltered) and " 3 " (highly altered) was established for each sample based on these criteria (Supplementary Note 3, Supplementary Figs. 3-7, Supplementary Tables 3-4) with samples scoring above "2.0" excluded from results. The same screening criteria have recently been used by Hearty et al..$^{10}$ and are discussed in Sandstrom et al. ${ }^{11}$. The latter also gives an overview of the limits and implications of SIS analyses for Plio-Pleistocene marine samples.

We selected Ostreidae species for SIS chronological constraints, primarily because these shells precipitate original calcite mineral phases, making them more robust to diagenesis than aragonitic shells. Sample screening and chemical 


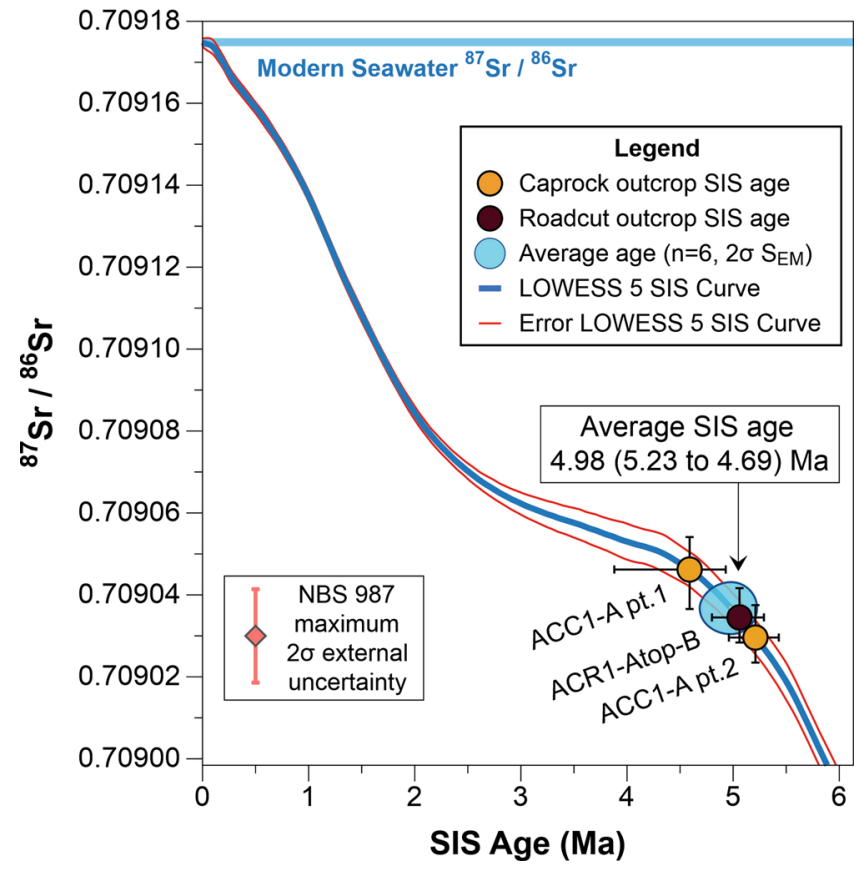

Fig. $5 \mathrm{Sr}$ isotope stratigraphy relative ages of oyster shells plotted on the SIS curve (LOWESS version 5) $\mathbf{6 4}^{\mathbf{4}}$. Orange points are from two separate portions of a shell from the Caprock, while maroon point is of a shell from unit $\mathbf{C p}$ in the Roadcut. The average SIS age based on these samples is shown as a blue ellipse. Only inner leaches on the best-preserved specimens are shown. For the full dataset, see Supplementary Note 3 annexed to this paper. Modern seawater ${ }^{87} \mathrm{Sr} /{ }^{86} \mathrm{Sr}$ values shown in light blue line. Maximum $2 \sigma$ external uncertainty for the $\mathrm{Sr}$ isotope external standard NBS 987 is shown as red point for comparison (see "Methods" section for details). processing was carried out at Lamont Doherty Earth Observatory (LDEO), and all ${ }^{87} \mathrm{Sr} /{ }^{86} \mathrm{Sr}$ measurements were made using Thermal Ion Mass Spectrometry (TIMS) on an IsotopX Phoenix at SUNY Stonybrook University (SBU) or a Finnigan Triton Plus at Lamont Doherty Earth Observatory (LDEO).

We measured three oyster shells, one from the Caprock and two from the Roadcut unit. The Caprock oyster (ACC1-A) was sampled in three different locations, with inner leaches measured on two of those splits, returning SIS ages of 4.59 Ma (3.88-4.93 Ma) and 5.21 Ma (4.96-5.44 Ma) (Fig. 5). The third sampling location was only measured for full dissolution, with an average SIS age of $4.65 \mathrm{Ma}$ $(4.42-4.83 \mathrm{Ma})$, but provided confidence in the shell $\mathrm{Sr}$ isotope heterogeneity and validated analytical uncertainties. The preservation index score for the caprock oyster(pt.1) was 1.92. The two shells measured from the Roadcut (ACR1-Atop-B and ACR1-Ctop-C) had inner leach SIS ages of $5.06 \mathrm{Ma}$ (4.80-5.28 Ma), and 6.35 $\mathrm{Ma}$ (6.19-6.53 Ma), respectively. Additional diagenesis screening techniques on these shells included elemental analysis (Supplementary Note 3), and variation of ${ }^{87} \mathrm{Sr} /{ }^{86} \mathrm{Sr}$ within the leach set of each sample. The results of sample variation compared to the inner leach ${ }^{87} \mathrm{Sr} /{ }^{86} \mathrm{Sr}$ are shown in the Supplementary Note 3, with low $\mathrm{Sr}$ isotope variation indicative of better preservation. Samples with low variation tend to exhibit more radiogenic ${ }^{87} \mathrm{Sr} /{ }^{86} \mathrm{Sr}$ values. Sample ACR1-Atop-B had a preservation index of 1.56, while ACR1-Ctop-C had a score of 2.33 (Supplementary Table 3). Based on these screening criteria, we exclude sample ACR1-Ctop-C, which appeared to have been altered by low ${ }^{87} \mathrm{Sr} /{ }^{86} \mathrm{Sr}$ fluids (possibly of through leaching of surrounding volcanic material from the Complejo Marifil ${ }^{38}$ ). The remaining inner leaches that passed screening were averaged by filament to obtain an age of $4.98+0.245 /-0.295 \mathrm{Ma}\left(n=6,2 \sigma \mathrm{S}_{\mathrm{EM}}\right)$. In the text, this age is reported as a $2 \sigma$ range, i.e., $4.69-5.23 \mathrm{Ma}$.

Glacial isostatic adjustment. To account for changes in vertical displacement and gravity field caused by GIA we use a gravitationally self-consistent sea level model, that accounts for the migration of shorelines and feedback of Earth's rotation axis $^{70}$. We compute both the contribution to GIA from the amount of residual deformation caused by the most recent Pleistocene glacial cycles and from ice age cycles during the Pliocene.

For the first contribution we use the results from Raymo et al. ${ }^{2}$, who calculated the residual deformation associated with the ice model ICE- $5 \mathrm{G}^{71}$. This ice history is paired with a suite of 36 different earth models with varying lithospheric thickness $(48 \mathrm{~km}, 71 \mathrm{~km}$, and $96 \mathrm{~km})$, upper and lower mantle viscosities $\left(3 \times 10^{20}\right.$ and $5 \times$ $10^{20} \mathrm{~Pa} \mathrm{~s}$ for the upper mantle, and $3 \times 10^{21}-30 \times 10^{21}$ for the lower mantle) to calculate a mean and standard deviation in residual deformation (Fig. 6).

For the second contribution we follow the approach described in Dumitru et al. ${ }^{9}$ by estimating ice mass variability based on the benthic stack ${ }^{50}$. Following Miller et al. ${ }^{72}$ we prescribe that $75 \%$ of the benthic $\delta^{18} \mathrm{O}$ variability is due to ice volume changes (the rest being due to temperature) and a further scaling of $0.11 \% / 10 \mathrm{~m}$ to a

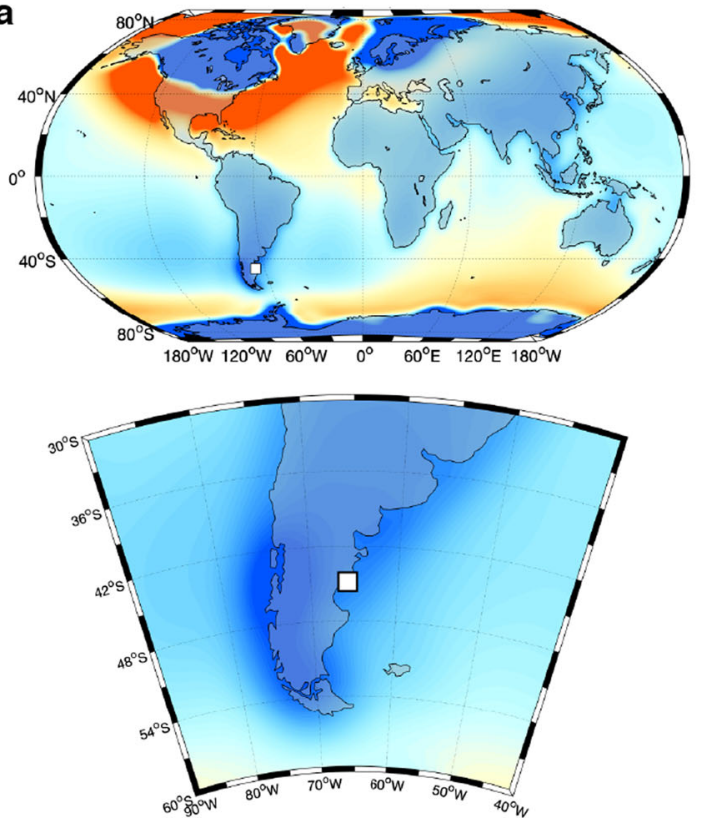

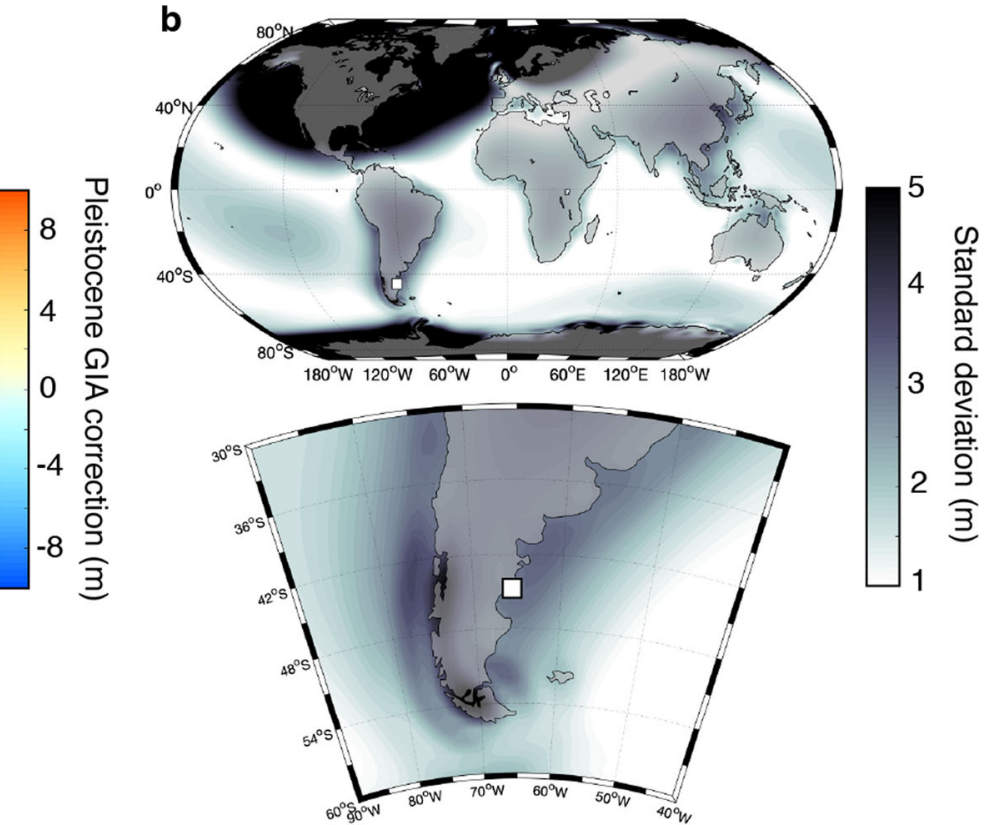

Fig. 6 GIA contribution due to ongoing adjustment. The maps show the GIA contribution caused by the incomplete present-day adjustment to the late Pleistocene ice and ocean loading cycles. a Model simulation using a viscosity structure of $5 \times 10^{20} \mathrm{~Pa}$ s viscosity in the upper mantle, $5 \times 10^{21} \mathrm{~Pa} \mathrm{~s}$ viscosity in the lower mantle, and an elastic lithospheric thickness of $96 \mathrm{~km}$. b Standard deviation of model predictions obtained using 36 different radial viscosity profiles, including varying the lithospheric thickness. The square in all insets marks the position of Camarones. 
convert $\delta^{18} O_{\text {seawater }}$ into ice volume changes. These conversions are highly uncertain $^{13,73}$, which highlights the need to obtain local sea level based ice volume estimates. Nonetheless, this scaling was used because it yielded comparable ice volume estimates to the results of Dumitru et al. ${ }^{9}$. To construct an ice history following this ice volume curve we only assume changes in Antarctic ice volume given evidence that continent wide expansion of northern hemisphere ice sheets did only start around 3.3 $\mathrm{Ma}^{74}$. However, we acknowledge that an earlier intermittent Greenland ice sheet might have existed ${ }^{75}$. We compute glacial isostatic adjustment using this ice history and the same suite of 36 different earth models described above. We extract local predictions of relative sea level for Argentina, Mallorca, and South Africa. To calculate global mean sea level changes we integrate the amount of water in the ocean basins as a function of time. We next calculate how this quantity has changed relative to the initial state and divide it by the oceanic area calculated at each time.

Note that this setup to calculate the GIA correction deviates slightly from the one described in Dumitru et al. ${ }^{9}$ in three small ways, (1) we only consider one GMSL history for the Pliocene rather than a range of histories, (2) we only consider variability in southern hemisphere ice sheets and (3) we calculated GMSL as described above rather than as changes in grounded ice volume.

The GIA corrections from both processes are combined. In a last step we consider the age range for each sea level indicator and average the GIA correction during warm periods, which we define as times that had higher than average sea level over this time period ${ }^{9}$. The mean and standard deviation that is obtained is shown in Table 3. We also show the GIA correction calculated by Dumitru et al. ${ }^{9}$ and note that the difference in mean GIA estimates stems mostly from our different definition of global mean sea level. For the analysis in the main text we use the GIA correction described in Dumitru et al..$^{9}$ for the datapoint from Mallorca and not the one recalculated here.

Vertical land motions. VLMs were extracted from published Dynamic Topography models ${ }^{45,46}$. The values extracted are reported in Table 2 . Flament et al. ${ }^{45}$ focus on the surface expression of subduction dynamics in South America. Their results are based on forward advection modeling with different tectonic surface boundary conditions. The different cases are based on different timings of slab flattening. Müller et al. ${ }^{46}$ have a global focus and combine back advection (initialized with a seismic tomography model) and forward advection with tectonic surface boundary conditions. Their different models are based on different surface plate reconstructions and different viscosity profiles.

\section{Data availability}

Spreadsheets containing GPS data, GMSL calculations, and details on shell preservation and ages are available from https://doi.org/10.5281/zenodo.3929150 39 (CC-BY 4.0 license). The GEOIDEAR16 geoid model was created by the Instituto Geográfico Nacional (Ministerio de Defensa, Argentina) and it was retrieved from the International Service for the Geoid http://www.isgeoid.polimi.it/. Plate boundaries in Fig. 1 and Fig. 3 were downloaded from GitHub: https://github.com/fraxen/tectonicplates/ (ODC-By license), and are derived from data by Peter Bird ${ }^{76}$, Hugo Ahlenius and Nordpil. The background shoreline maps in Fig. 3a and Fig. 6 were retrieved from NOAA-NCEI (Global Selfconsistent Hierarchical High-resolution Shoreline, GSHHS ${ }^{77}$ ). Equation (1) was derived from a StackExchange discussion (https://stats.stackexchange.com/questions/25848/howto-sum-a-standard-deviation). Samples described in this study were registered in the System for Earth Sample Registration https://www.geosamples.org/, and assigned an International Geo-Sample number (IGSN). Dynamic topography model outputs were obtained from the Gplates portal (http://portal.gplates.org/).

\section{Code availability}

The python scripts used to produce panels b and c of Fig. 3 and the main panel of Fig. 4 are available from https://doi.org/10.5281/zenodo.3689426 $6^{78}$ (MIT license). The computer code used to do the sea-level (GIA) calculation, written in MATLAB, is available on GitHub (https://github.com/jaustermann/SLcode).

Received: 21 October 2020; Accepted: 19 November 2020; Published online: 23 December 2020

\section{References}

1. Rovere, A. et al. The analysis of Last Interglacial (MIS 5e) relative sea-level indicators: reconstructing sea-level in a warmer world. Earth-Sci. Rev. 159, 404-427 (2016).

2. Raymo, M. E., Mitrovica, J. X., O’Leary, M. J., DeConto, R. M. \& Hearty, P. J. Departures from eustasy in Pliocene sea-level records. Nat. Geosci. 4, 328-332 (2011).

3. Austermann, J., Mitrovica, J. X., Huybers, P. \& Rovere, A. Detection of a dynamic topography signal in Last Interglacial sea-level records. Sci. Adv. 3, e1700457 (2017).

4. Dutton, A. et al. Sea-level rise due to polar ice-sheet mass loss during past warm periods. Science 349, aaa4019 (2015).
5. DeConto, R. M. \& Pollard, D. Contribution of Antarctica to past and future sea-level rise. Nature 531, 591-597 (2016).

6. Khan, N. S. et al. Inception of a global atlas of sea levels since the Last Glacial Maximum. Quat. Sci. Rev. 220, 359-371 (2019).

7. Pedoja, K. et al. Coastal staircase sequences reflecting sea-level oscillations and tectonic uplift during the Quaternary and Neogene. Earth-Sci. Rev. 132, 13-38 (2014)

8. Rovere, A. et al. The Mid-Pliocene sea-level conundrum: glacial isostasy, eustasy and dynamic topography. Earth Planet. Sci. Lett. 387, 27-33 (2014).

9. Dumitru, O. A. et al. Constraints on global mean sea level during Pliocene warmth. Nature 574, 233-236 (2019).

10. Hearty, P. J. et al. Pliocene-pleistocene stratigraphy and sea-level estimates, Republic of South Africa with implications for a $400 \mathrm{ppmv} \mathrm{CO}_{2}$ world. Paleoceanogr. Paleoclimatol. 35, e2019PA003835 (2020).

11. Sandstrom, M. R. et al. Age constraints on surface deformation recorded by fossil shorelines at Cape Range, Western Australia. GSA Bullet. https://doi.org/ 10.1130/B35564.1 (2020).

12. Rohling, E. et al. Sea-level and deep-sea-temperature variability over the past 5.3 million years. Nature 508, 477-482 (2014)

13. Raymo, M. E., Kozdon, R., Evans, D., Lisiecki, L. \& Ford, H. L. The accuracy of Mid-Pliocene $\delta 18 \mathrm{o}-$ based ice volume and sea level reconstructions. Earth-Sci. Rev. 177, 291-302 (2018).

14. Miller, K. G. et al. Cenozoic sea-level and cryospheric evolution from deep-sea geochemical and continental margin records. Sci. Adv. 6, eaaz1346 (2020).

15. Haywood, A. M. et al. Are there pre-Quaternary geological analogues for a future greenhouse warming? Philos. Trans. R. Soc. A 369, 933-956 (2011).

16. Fedorov, A. et al. Patterns and mechanisms of Early Pliocene warmth. Nature 496, 43-49 (2013)

17. Lunt, D. J. et al. Earth system sensitivity inferred from Pliocene modelling and data. Nat. Geosci. 3, 60-64 (2010).

18. Grant, G. et al. The amplitude and origin of sea-level variability during the Pliocene epoch. Nature 574, 237-241 (2019).

19. Solgaard, A. M., Reeh, N., Japsen, P. \& Nielsen, T. Snapshots of the Greenland Ice Sheet configuration in the Pliocene to Early Pleistocene. J. Glaciol. 57, 871-880 (2011).

20. Naish, T. et al. Obliquity-paced Pliocene West Antarctic ice sheet oscillations. Nature 458, 322-328 (2009)

21. Pollard, D. \& DeConto, R. M. Modelling West Antarctic Ice Sheet growth and collapse through the past five million years. Nature 458, 329-332 (2009).

22. Cook, C. P. et al. Dynamic behaviour of the East Antarctic Ice Sheet during Pliocene warmth. Nat. Geosci. 6, 765-769 (2013).

23. Dolan, A. M. et al. Sensitivity of Pliocene ice sheets to orbital forcing. Palaeogeogr. Palaeoclimatol. Palaeoecol. 309, 98-110 (2011).

24. Thomas, C., Livermore, R. \& Pollitz, F. Motion of the Scotia sea plates. Geophys. J. Int. 155, 789-804 (2003).

25. Rabassa, J. Late cenozoic glaciations in Patagonia and Tierra del Fuego. Dev. Quat. Sci. 11, 151-204 (2008).

26. Guillaume, B., Martinod, J., Husson, L., Roddaz, M. \& Riquelme, R. Neogene uplift of central eastern Patagonia: dynamic response to active spreading ridge subduction? Tectonics 28, https://doi.org/10.1029/2008TC002324 (2009).

27. Ton-That, T., Singer, B., Mörner, N.-A. \& Rabassa, J. Datación de lavas basálticas por ${ }^{40} \mathrm{Ar} /{ }^{39} \mathrm{Ar}$ y geología glacial de la región del lago Buenos Aires, provincia de Santa Cruz, Argentina. Revista de la Asociación Geológica Argentina 54, 333-352 (1999)

28. Darwin, C. Geological observations on South America: Being the third part of the geology of the voyage of the Beagle, under the command of Capt. Fitzroy, $R N$ during the years 1832 to 1836, 65 (Smith, Elder and Company, Cornhill., 1846).

29. Schellmann, G. \& Radtke, U. Coastal terraces and holocene sea-level changes along the patagonian atlantic coast. J. Coast. Res. 19, 983-996 (2003).

30. Zanchetta, G. et al. Middle-to late-holocene relative sea-level changes at Puerto Deseado (Patagonia, Argentina). Holocene 24, 307-317 (2014).

31. Pappalardo, M. et al. Coastal landscape evolution and sea-level change: a case study from central Patagonia (Argentina). Zeitschrift für Geomorphol. 59, 145-172 (2015).

32. Rostami, K., Peltier, W. \& Mangini, A. Quaternary marine terraces, sea-level changes and uplift history of Patagonia, Argentina: comparisons with predictions of the ice-4g (VM2) model of the global process of glacial isostatic adjustment. Quat. Sci. Rev. 19, 1495-1525 (2000).

33. Schellmann, G. \& Radtke, U. ESR dating stratigraphically well-constrained marine terraces along the Patagonian atlantic coast (Argentina). Quat. Int. 68, 261-273 (2000).

34. Rutter, N. et al. Correlation and dating of Quaternary littoral zones along the Patagonian coast, Argentina. Quat. Sci. Rev. 8, 213-234 (1989).

35. Del Río, C., Griffin, M., McArthur, J., Martínez, S. \& Thirlwall, M. Evidence for early Pliocene and late Miocene transgressions in southern Patagonia 
(Argentina): ${ }^{87} \mathrm{Sr} /{ }^{86} \mathrm{Sr}$ ages of the pectinid "Chlamys" actinodes (Sowerby). J. South Am. Earth Sci. 47, 220-229 (2013).

36. Bini, M. et al. Mid-holocene relative sea-level changes along atlantic Patagonia: new data from Camarones, Chubut, Argentina. Holocene 28, 56-64 (2018).

37. Feruglio, E. Descripción geológica de la Patagonia, Vol. 1 (Impr. y Casa Editora "Coni", 1949).

38. Lema, H. A. et al. Hoja Geológica 4566-II y IV Camarones (Servicio Geológico Minero Argentino. Instituto de Geología y Recursos Minerales, 2001).

39. Rovere, A. et al. Survey data, models and dated samples of the Pliocene shorelines of Camarones, Argentina (ver 1.1). (2020).

40. Piñón, D., Zhang, K., Wu, S. \& Cimbaro, S. A new argentinean gravimetric geoid model: GEOIDEAR. In International Symposium on Earth and Environmental Sciences for Future Generations, 53-62 (Springer, 2017).

41. Braun, J. The many surface expressions of mantle dynamics. Nat. Geosci. 3 , 825-833 (2010).

42. Moucha, R. et al. Dynamic topography and long-term sea-level variations: there is no such thing as a stable continental platform. Earth Planet. Sci. Lett. 271, 101-108 (2008).

43. Moucha, R. \& Ruetenik, G. A. Interplay between dynamic topography and flexure along the US Atlantic passive margin: insights from landscape evolution modeling. Global Planet. Change 149, 72-78 (2017).

44. Ferrier, K. L., Austermann, J., Mitrovica, J. X. \& Pico, T. Incorporating sediment compaction into a gravitationally self-consistent model for ice age sea-level change. Geophys. J. Int. 211, 663-672 (2017).

45. Flament, N., Gurnis, M., Müller, R. D., Bower, D. J. \& Husson, L. Influence of subduction history on South American topography. Earth Planet. Sci Lett. 430, 9-18 (2015).

46. Müller, R. D., Hassan, R., Gurnis, M., Flament, N. \& Williams, S. E. Dynamic topography of passive continental margins and their hinterlands since the Cretaceous. Gondwana Res. 53, 225-251 (2018).

47. Richards, F. D., Hoggard, M. J., White, N. \& Ghelichkhan, S. Quantifying the relationship between short-wavelength dynamic topography and thermomechanical structure of the upper mantle using calibrated parameterization of anelasticity. J. Geophys. Res. 125, e2019JB019062 (2020).

48. Lloyd, A. J. et al. Decoding cenozoic tectonics in Patagonia, the scotia sea, and the Antarctic peninsula from new seismic tomography. AGUFM 2019, T41J-0286 (2019).

49. Stocchi, P. et al. MIS 5e relative sea-level changes in the Mediterranean sea: contribution of isostatic disequilibrium. Quat. Sci. Rev. 185, 122-134 (2018).

50. Lisiecki, L. E. \& Raymo, M. E. A Pliocene-Pleistocene stack of 57 globally distributed benthic $\delta^{18} \mathrm{O}$ records. Paleoceanography $20 \mathrm{https} / /$ doi.org/ 10.1029/2004PA001071 (2005).

51. Stap, L. B., Van De Wal, R. S., De Boer, B., Bintanja, R. \& Lourens, L. J. The influence of ice sheets on temperature during the past 38 million years inferred from a one-dimensional ice sheet-climate model. Clim. Past 13, 1243-1257 (2017).

52. De Boer, B., Van de Wal, R., Bintanja, R., Lourens, L. \& Tuenter, E. Cenozoic global ice-volume and temperature simulations with 1-d ice-sheet models forced by benthic $\delta^{18} \mathrm{O}$ records. Ann. Glaciol. 51, 23-33 (2010).

53. De Boer, B., Lourens, L. J. \& Van De Wal, R. S. Persistent 400,000-year variability of Antarctic ice volume and the carbon cycle is revealed throughout the Plio-pleistocene. Nat. Commun. 5, 2999 (2014)

54. Stap, L. B. et al. $\mathrm{CO}_{2}$ over the past 5 million years: continuous simulation and new $\delta^{11 \mathrm{~B}}$-based proxy data. Earth Planet. Sci. Lett. 439, 1-10 (2016).

55. Morlighem, M. et al. Bedmachine v3: complete bed topography and ocean bathymetry mapping of Greenland from multibeam echo sounding combined with mass conservation. Geophys. Res. Lett. 44, 11-051 (2017).

56. Bamber, J. L., Riva, R. E., Vermeersen, B. L. \& LeBrocq, A. M. Reassessment of the potential sea-level rise from a collapse of the West Antarctic Ice Sheet. Science 324, 901-903 (2009).

57. Fretwell, P. et al. BEDMAP2: improved ice bed, surface and thickness datasets for Antarctica. Cryosphere 7, 375-393 (2013).

58. Golledge, N. R. et al. Antarctic climate and ice-sheet configuration during the early Pliocene interglacial at 4.23 Ma. Clim. Past 13, 959-975 (2017).

59. Shakun, J. D. et al. Minimal East Antarctic Ice Sheet retreat onto land during the past eight million years. Nature 558, 284-287 (2018).

60. Rogelj, J. et al. Paris agreement climate proposals need a boost to keep warming well below 2 C. Nature 534, 631-639 (2016).

61. IPCC. Global warming of 1.5 C. An IPCC Special Report on the impacts of global warming of $1.5 \mathrm{C}$ above pre-industrial levels and related global greenhouse gas emission pathways, in the context of strengthening the global response to the threat of climate change, sustainable development, and efforts to eradicate poverty (2018).

62. Shennan, I. Flandrian sea-level changes in the Fenland. II: tendencies of sealevel movement, altitudinal changes, and local and regional factors. J. Quat. Sci. 1, 155-179 (1986).
63. Green, J., Huber, M., Waltham, D., Buzan, J. \& Wells, M. Explicitly modelled deep-time tidal dissipation and its implication for lunar history. Earth Planet. Sci. Lett. 461, 46-53 (2017).

64. McArthur, J., Howarth, R. \& Shields, G. Strontium isotope stratigraphy. Geologic Time Scale 1, 127-144 (2012).

65. Bailey, T., McArthur, J., Prince, H. \& Thirlwall, M. Dissolution methods for strontium isotope stratigraphy: whole rock analysis. Chem. Geol. 167, 313-319 (2000).

66. Li, D., Shields-Zhou, G. A., Ling, H.-F. \& Thirlwall, M. Dissolution methods for strontium isotope stratigraphy: Guidelines for the use of bulk carbonate and phosphorite rocks. Chem. Geol. 290, 133-144 (2011).

67. McArthur, J. M. Recent trends in strontium isotope stratigraphy. Terra Nova 6, 331-358 (1994).

68. Brand, U. \& Veizer, J. Chemical diagenesis of a multicomponent carbonate system; 1, trace elements. J. Sediment. Res. 50, 1219-1236 (1980).

69. Gothmann, A. M. et al. Fossil corals as an archive of secular variations in seawater chemistry since the mesozoic. Geochim. et Cosmochim. Acta 160, 188-208 (2015).

70. Kendall, R. A., Mitrovica, J. X. \& Milne, G. A. On post-glacial sea level-II numerical formulation and comparative results on spherically symmetric models. Geophys. J. Int. 161, 679-706 (2005).

71. Peltier, W. Global glacial isostasy and the surface of the ice-age earth: the ICE-5g (VM2) model and grace. Ann. Rev. Earth Planet. Sci. 32, 111-149 (2004).

72. Miller, K. G. et al. High tide of the warm Pliocene: implications of global sea level for Antarctic deglaciation. Geology 40, 407-410 (2012).

73. Gasson, E., DeConto, R. M. \& Pollard, D. Modeling the oxygen isotope composition of the Antarctic Ice Sheet and its significance to Pliocene sea level. Geology 44, 827-830 (2016).

74. Jansen, E., Fronval, T., Rack, F. \& Channell, J. E. T. Pliocene-Pleistocene ice rafting history and cyclicity in the nordic seas during the last 3.5 myr. Paleoceanography 15, 709-721 (2000).

75. Bierman, P. R., Shakun, J. D., Corbett, L. B., Zimmerman, S. R. \& Rood, D. H A persistent and dynamic east Greenland Ice Sheet over the past 7.5 million years. Nature 540, 256-260 (2016).

76. Bird, P. An updated digital model of plate boundaries. Geochem. Geophys. Geosyst. 4 (2003).

77. Wessel, P. \& Smith, W. H. A global, self-consistent, hierarchical, highresolution shoreline database. J. Geophys. Res. 101, 8741-8743 (1996).

78. Rovere, A. Paleo sea level utilities (ver 1.5) (2020)

79. United States Geological Survey. Shuttle Radar Topography Mission (SRTM) 1 arc-second global. version 3.0 (2015).

\section{Acknowledgements}

This research was among the primary objectives of the PLIOMAX grant, NSF OCE1202632 (PI MER and co-PI PJH). A.R. acknowledges the Institutional Strategy of the University of Bremen, German Excellence Initiative (ABPZuK-03/2014) for support. M.E.R. and J.A. acknowledge the additional support of the G. Unger Vetlesen Foundation. M.A. acknowledges the following projects: Agencia Nacional de Promoción Científica y Tecnológica (PICT 2006-468, PICT 2013-1298), CONICET (PIP 0080, 0372 and 0729), and Universidad Nacional de La Plata (PI N11/587 and N11/726). The authors acknowledge PALSEA for useful discussions during annual meetings. PALSEA is a working group of the International Union for Quaternary Sciences (INQUA) and Past Global Changes (PAGES), which in turn received support from the Swiss Academy of Sciences and the Chinese Academy of Sciences. We acknowledge Deirdre Ryan and Evan Gowan for useful discussions in the field, and Karla Rubio Sandoval Zurisadai for comments on the final draft of the MS. The background maps in Fig. 1 of this article were created using ArcGIS ${ }^{\oplus}$ software by Esri. ArcGIS ${ }^{\oplus}$ and $\operatorname{ArcMap}^{\mathrm{TM}}$ are the intellectual property of Esri and are used herein under license. Copyright $\left.{ }^{(}\right)$Esri. All rights reserved. For more information about Esri ${ }^{\circledR}$ software, please visit www.esri.com.

\section{Author contributions}

A.R., M.P., and S.R. wrote the MS and supplementary materials, including figures. S.R. elaborated the stratigraphic description of the Roadcut outcrop. M.A. provided expertize on the faunal composition of the Roadcut and Caprock outcrops. M.R.S. performed SIS dating and contributed text on SIS methods and results. J.A. produced GIA estimates, advised on DT and GMSL calculations, and contributed to the writing of the paper. P.J. $\mathrm{H}$. provided expertize on stratigraphic and geological interpretation on the Camarones outcrops. All authors (except J.A.) participated in different phases of the field expeditions to Camarones. IC identified the Caprock site in the field. M.E.R. provided expertize on the paleoclimatic implications of the study. All authors revised the main text and Supplementary Information, and agree with its contents.

\section{Funding}

Open Access funding enabled and organized by Projekt DEAL. 


\section{Competing interests}

The authors declare no competing interests

\section{Additional information}

Supplementary information is available for this paper at https://doi.org/10.1038/s43247020-00067-6

Correspondence and requests for materials should be addressed to A.R.

Peer review information Primary handling editor: Heike Langenberg.

Reprints and permission information is available at http://www.nature.com/reprints

Publisher's note Springer Nature remains neutral with regard to jurisdictional claims in published maps and institutional affiliations. (c) (i) Open Access This article is licensed under a Creative Commons Attribution 4.0 International License, which permits use, sharing, adaptation, distribution and reproduction in any medium or format, as long as you give appropriate credit to the original author(s) and the source, provide a link to the Creative Commons license, and indicate if changes were made. The images or other third party material in this article are included in the article's Creative Commons license, unless indicated otherwise in a credit line to the material. If material is not included in the article's Creative Commons license and your intended use is not permitted by statutory regulation or exceeds the permitted use, you will need to obtain permission directly from the copyright holder. To view a copy of this license, visit http://creativecommons.org/ licenses/by/4.0/.

(c) The Author(s) 2020 